\title{
Operational risk management in financing environmental activities and personnel management projects
}

\author{
Aleksandr Bril $^{1}$, Olga Kalinina ${ }^{1}$, Alina Kankovskaya ${ }^{1,{ }^{*},}$ and Viktoria Vilken ${ }^{1}$ \\ ${ }^{1}$ Peter the Great St. Petersburg Polytechnic University, 195271 Saint-Petersburg, Russia
}

\begin{abstract}
Projects on environmental protection and personnel management have a significant impact on the level of fixed costs and changes in operational risks of industrial enterprises. The most effective implementation of these projects is possible at the stages of production growth and expansion of sales of companies. At the stages of recession, this work requires strict control over the level of operational risk and changes in the share of fixed costs in the cost of production. Improving the efficiency of environmental and personnel management projects requires maintaining an optimal level of operational risk. It is proposed to retain project risks at the planned level by controlling and regulating the amount of fixed costs at the enterprises. Various regulatory systems are proposed for periods of recovery and recession of economic activity of enterprises.
\end{abstract}

\section{Introduction}

The relationship between risk and return is a key concept in business financial management. High levels of risk drive high returns. Lower risk or avoidance of risk requires significant additional costs and, therefore, results in lower profit and return.

Risk arises mainly due to uncertainty of the business environment. This uncertainty hides risk causes and factors shaping a risk situation. The causes of risk include political, social, environmental, technological and other conditions of public life and environment. Risk factors are the circumstances in which the causes of risk manifest and lead to risk situations.

Risk situation is an event associated with risk causes and factors, which can have negative or positive consequences for the enterprise. Complex projects of enterprise development, environmental projects and personnel management systems improvement projects require significant financial investments and create risk situations. These risk situations lead to a deviation of actual performance from planned outputs. In practical terms, these deviations lead to loss of profit and falling profitability of operating enterprises.

Risk management theory and practice are aimed at guaranteed reduction of undesirable deviations. Risk management involves taking a decision on risk management in case of presence of several alternative solutions determining the possibility of using limited

\footnotetext{
*Corresponding author: kankovskaya_ar@spbstu.ru
} 
resources. In this regard, risk management at the stage of work planning requires processes simulation and various situations monitoring during the implementation of enterprise development projects.

The risk management process should accompany the stages of planning and decisionmaking under the most important issues. This applies primarily to changes in company policies, introduction of new strategies and procedures, project management, large money investments or optimization of internal organizational conflicts and contradictions. This includes environmental planning and enterprise personnel management. The resulting assessment of the final (acceptable) level of risk may significantly change the view on the activity's efficiency. Given the measures taken to reduce the risk, the final risk level may become acceptable in a possible risk situation.

The authors focus on the following approach to risk management:

- risk is a controlled parameter, the level of which can and should be managed;

- only the identified, analyzed and assessed risk can be managed.

For the situation of environmental planning fixed costs of the enterprise are taken as a managed risks parameter. The fixed costs level and share in total cost directly affect such quantitative characteristics of operational risk as operating leverage, break-even threshold and financial safety margin.

Many operational risks at industrial enterprises are connected with the proportion of fixed and variable costs. Environmental finance usually provides for an increase in the fixed component of operating costs and an increase in operational risks [1-5]. Environmental planning and management are directly associated with personnel management projects and, therefore, with modification of the proportion of fixed and variable costs in the cost of production [6-9].

Risk management practices provide for risk mitigation and risk reduction strategies [10, 11]. Risk mitigation strategies include risk avoidance, retention, transfer and reduction. Risk avoidance means simple avoidance of activities associated with risk. However, risk avoidance often means that the investor is deprived of profit.

Risk retention implies that risk is retained by the investor, i.e. within the investor's responsibility. It should be noted that due to operational risk, any change in sales always leads to drastic changes in operating income. Therefore, risk retention is key to improve the efficiency of environmental activities and personnel management projects.

It should be noted that the optimal level of operational risk for industrial enterprises may significantly differ during economic recovery or recession at the enterprise or in the industry to which it belongs. That is why we have conducted a special study of the correlation between changes in fixed costs and operational risks at various enterprises during the sales growth and economic recession periods.

\section{Study}

Personnel management improvement at enterprises to a large extent aims at personnel reduction and labour productivity increase [12-15]. Consequently, when implemented, such improvement projects modify the proportion of the company's fixed and variable costs and affect the level of operational risk. When analysing the efficiency of various project options, it is necessary to make a quantitative evaluation of such projects. Such evaluation involves the calculation of operating leverage and is an essential component of the economic evaluation for one-phase project assessment.

Operating leverage, break-even analysis and calculation of margin of safety are the most common types of project quantitative evaluation. 
The degree of operating leverage $(D O L)$ is the amount of fixed costs maintained in the enterprise's operations. Higher operating leverage and, therefore, the percentage of fixed costs, mean higher operational risks.

$D O L$ is calculated as follows:

$$
D O L=C M / O I
$$

where $C M$ means contribution margin (the amount available to cover fixed costs plus operating income); $O I$ means operating income.

Contribution margin $(C M)$ is calculated by subtracting total variable costs $(T V C)$ from sales:

$$
C M=\text { Sales }-T V C
$$

As contribution margin is the amount available to cover fixed costs plus operating income, the amounts of operating leverage and, therefore, operational risk depend on the percentage of fixed costs in total costs. The proportion of fixed and variable costs at various enterprises reflects the level of operational risk and, therefore, affects the rate of return, which can be controlled using the operating leverage mechanism. So operating income growth $(O I G)$ depends on sales growth $(S G)$ as follows:

$$
O I G=S G \cdot D O L
$$

i.e. if $D O L$ is 3.0 , sales growth by $1 \%$ means operating income growth by $3 \%$. If $D O L$ decreases to 2.0 , the same sales growth by $1 \%$ means operating income growth by only $2 \%$.

Break-even analysis and break-even point calculation are used to determine a point at which sales are sufficient to cover all costs without making any profit.

A break-even point $(B E P)$ is calculated using the following formula:

$$
B E P=T F C /(1-C M R)
$$

where $T F C$ means total fixed costs;

CMR means contribution margin ratio, which expresses variable costs as a percentage of sales:

$$
C M R=T V C / S,
$$

where $T V C$ means total variable costs; $S$ means annual (or monthly) sales.

Calculations contain fixed and variable costs for the same period as sales.

A break-even point is very important for business planning as it helps to evaluate the risk of decrease in demand and sales.

The last stage of break-even analysis usually involves calculation of margin of safety. It is a difference between actual or budgeted sales and a break-even point. It is the indicator that determines the level of business risk that an enterprise faces. Higher margin of safety during personnel management project implementation means lower production risks, while lower margin of safety means higher risks.

This article presents findings of the study of changes in the level of operational risks at enterprises with high and low percentage of fixed costs in the cost of production depending on increasing or decreasing budgeted sales.

Table 1 shows that at the growth stage sales growth by $10 \%$ means that fixed costs in various enterprise groups falls from 0.30 to 0.28 , i.e. by 6.7 percent, and from 0.60 to 0.58 , i.e. by 3.3 percent. Operational risks also decrease. Operating leverage falls from 3.7 to 2.97 and from 6.4 to 4.29 . It falls more at enterprises with higher initial level of risk. Margin of safety rises by 37 and by $64 \%$ also depending on the initial level of operational risk, which is determined based on the percentage of fixed costs in the cost of production. Decreasing level of risk will later lead to a relative decrease in operating income growth as 
compared to sales growth. This is when it is necessary to keep operational risks at an initial level to ensure sufficient efficiency of new personnel management projects.

At the same time the study shows that sales slowdown and decrease by $10 \%$ lead to an increase in fixed costs from 0.30 up to 0.32 , i.e. by 6.7 percent and from 0.60 up to 0.62 , i.e. by 3.3 percent. Operating leverage for enterprises with relatively low percentage of fixed costs rises from 3.7 to 5.29, i.e. becomes 1.43 times higher.

Table 1. Decrease in operational risks due to sales growth.

\begin{tabular}{|c|c|c|c|c|}
\hline Margin & $\begin{array}{c}\text { Enterprise } \\
\text { with low } \\
\text { percentage of } \\
\text { fixed costs } \\
\mathbf{3 0} \% \\
\end{array}$ & $\begin{array}{c}\text { Changes in } \\
\text { indicators } \\
\text { after an } \\
\text { increase in } \\
\text { sales by } 10 \% \\
\end{array}$ & $\begin{array}{c}\text { Enterprise } \\
\text { with high } \\
\text { percentage of } \\
\text { fixed costs } \\
60 \% \\
\end{array}$ & $\begin{array}{c}\text { Changes in } \\
\text { indicators } \\
\text { after an } \\
\text { increase in } \\
\text { sales by } 10 \% \\
\end{array}$ \\
\hline Sales & 24,000 & 26,400 & 24,000 & 26,400 \\
\hline $\begin{array}{l}\text { Cost of goods } \\
\text { sold, } \\
\text { including } \\
\text { variable costs } \\
\text { fixed costs } \\
\end{array}$ & $\begin{array}{c}21,600 \\
\\
15,120 \\
6,480 \\
\end{array}$ & $\begin{array}{c}23,112 \\
\\
16,632 \\
6,480 \\
\end{array}$ & $\begin{array}{c}21,600 \\
\\
8,640 \\
12,960 \\
\end{array}$ & $\begin{array}{c}22,464 \\
\\
9,504 \\
12,960 \\
\end{array}$ \\
\hline $\begin{array}{l}\text { Percentage of } \\
\text { variable costs } \\
\text { in the cost }\end{array}$ & 0.70 & 0.72 & 0.40 & 0.42 \\
\hline $\begin{array}{l}\text { Percentage of } \\
\text { fixed costs in } \\
\text { the cost }\end{array}$ & 0.30 & 0.28 & 0.60 & 0.58 \\
\hline $\begin{array}{l}\text { Operating } \\
\text { income }\end{array}$ & 2,400 & 3,288 & 2,400 & 3,936 \\
\hline $\begin{array}{c}\text { Sales } \\
\text { increment in } \\
\text { profit, percent }\end{array}$ & & 37 & & 64 \\
\hline $\begin{array}{c}\text { Annual } \\
\text { turnover } \\
\text { increment } \\
\text { rate, percent }\end{array}$ & & 10 & & 10 \\
\hline $\begin{array}{l}\text { Operating } \\
\text { income } \\
\text { growth }\end{array}$ & & 0.370 & & 0.640 \\
\hline $\begin{array}{l}\text { Annual sales } \\
\text { growth rate }\end{array}$ & & 0.100 & & 0.100 \\
\hline $\begin{array}{c}\text { Contribution } \\
\text { margin }\end{array}$ & 8,880 & 9,768 & 15,360 & 16,896 \\
\hline DOL & 3.70 & 2.97 & 6.40 & 4.29 \\
\hline $\begin{array}{c}\text { Break-even } \\
\text { point }\end{array}$ & 17,514 & 17,514 & 20,250 & 20,250 \\
\hline $\begin{array}{l}\text { Margin of } \\
\text { safety }\end{array}$ & 6,486 & 8,886 & 3,750 & 6,150 \\
\hline $\begin{array}{c}\text { Margin of } \\
\text { safety growth, } \\
\text { percent }\end{array}$ & & 37 & & 64 \\
\hline
\end{tabular}

Operating leverage for enterprises with high initial operational risks (fixed costs of $60 \%$ ) becomes 2.5 times higher and rises from 6.4 to 16. Margin of safety becomes 1.6 and 2.8 times lower for enterprises with low $(30 \%)$ and high $(60 \%)$ percentage of fixed costs in 
the cost of production, respectively (Table 2). It is necessary to compensate for the increased risks, keeping them at the initial level to ensure normal operation of the company during economic recession.

Table 2. Operational risks elevation at enterprises in the conditions of sales volumes reduction.

\begin{tabular}{|c|c|c|c|c|}
\hline & $\begin{array}{l}\text { Low fixed costs } \\
\text { enterprise } 30 \\
\text { percent }\end{array}$ & $\begin{array}{l}\text { Change in } \\
\text { results in case } \\
\text { of revenue } \\
\text { decrease by } \\
10 \text { percent }\end{array}$ & $\begin{array}{l}\text { High fixed } \\
\text { costs enterprise } \\
60 \text { percent }\end{array}$ & $\begin{array}{c}\text { Change in } \\
\text { results in } \\
\text { case of } \\
\text { revenue } \\
\text { decrease by } \\
10 \text { percent }\end{array}$ \\
\hline Products sales volume & 24,000 & 21,600 & 24,000 & 21,600 \\
\hline Cost of products sold & 21,600 & 20,088 & 21,600 & 20,736 \\
\hline including variable costs & 15,120 & 13,608 & 8,640 & 7,776 \\
\hline fixed costs & 6,480 & 6,480 & 12,960 & 12,960 \\
\hline $\begin{array}{l}\text { Variable costs share in } \\
\text { cost of products }\end{array}$ & 0.70 & 0.68 & 0.40 & 0.38 \\
\hline $\begin{array}{c}\text { Fixed costs share in cost } \\
\text { of products }\end{array}$ & 0.30 & 0.32 & 0.60 & 0.62 \\
\hline Sales profit & 2,400 & 1,512 & 2,400 & 864 \\
\hline $\begin{array}{l}\text { Decrease in profit from } \\
\text { sales, percent }\end{array}$ & & 37 & & 64 \\
\hline $\begin{array}{l}\text { Annual turnover } \\
\text { reduction rate, percent }\end{array}$ & & 10 & & 10 \\
\hline Marginal profit & 8,880 & 7,992 & 15,360 & 13,824 \\
\hline $\mathrm{OL}$ & 3.70 & 5.29 & 6.40 & 16.00 \\
\hline Break-even point & 17,514 & 17,514 & 20,250 & 20,250 \\
\hline Financial safety margin & 6,486 & 4,086 & 3,750 & 1,350 \\
\hline $\begin{array}{c}\text { Financial safety margin } \\
\text { decrease }\end{array}$ & & 1.59 & & 2.78 \\
\hline
\end{tabular}

Based on this study involving an evaluation of the effect of the proportion of fixed and variable costs in the cost of production on the level of operational risks, it is possible to recommend various behavioral patterns for personnel management arrangements at industrial enterprises.

An enterprise faces the need to reduce the number of nonproduction workers only during economic recession and sales decrease at the enterprise. While during sales growth operational risk retention allows the introduction of additional positions of nonproduction workers and other elements providing for an increase in fixed costs. A mechanism and effective amounts of changes in fixed costs should be selected for each specific enterprise based on the analysis of external and internal production situation.

The results of the study provide the opportunity to use information on changes in operational risks to forecast and plan sales, production and personnel management systems for different groups of enterprises.

Table 3 shows a monitoring scheme when forecasting the growth of sales and profits of enterprises planning to have environmental projects and finance environmental activities. The growth of planned turnover of the company and necessary investments in assets for this purpose are ensured by undistributed profit and short-term credit. 
Table 3. Planned increase in sales revenue and investment in assets of the enterprise.

\begin{tabular}{|c|c|c|c|c|c|c|}
\hline \multirow{2}{*}{$\begin{array}{c}\text { Financial } \\
\text { indicators }\end{array}$} & \multicolumn{5}{|c|}{ Variable costs share in cost of products, percent } \\
\cline { 2 - 7 } & $\mathbf{3 0}$ & $\mathbf{4 0}$ & $\mathbf{5 0}$ & $\mathbf{7 0}$ & $\mathbf{8 0}$ & $\mathbf{9 0}$ \\
\hline $\begin{array}{c}\text { Asset turnover } \\
\text { Return on sales } \\
\text { (ROS), percent } \\
\text { ROA }\end{array}$ & 2.62 & 2.62 & 2.62 & 2.62 & 2.62 & 2.62 \\
\hline ROE & $13.7 \%$ & $13.6 \%$ & $13.4 \%$ & $12.6 \%$ & $12.0 \%$ & $10.7 \%$ \\
\hline $\begin{array}{c}\text { Debt ratio, Dr } \\
\text { Financial } \\
\text { independence } \\
\text { ratio }\end{array}$ & 0.56 & 0.57 & 0.58 & 0.64 & 0.68 & 0.77 \\
$\begin{array}{c}\text { Net profit share } \\
\text { in revenue, } \\
\text { percent }\end{array}$ & 2.63 & 2.59 & 2.55 & 2.42 & 2.29 & 2.05 \\
$\begin{array}{c}\text { Operating } \\
\text { leverage, OL } \\
\text { Rate of profit } \\
\text { growth from } \\
\text { sales }\end{array}$ & 10.75 & 9.36 & 7.97 & 5.18 & 3.79 & 2.39 \\
$\begin{array}{c}\text { Revenue growth } \\
\text { rate }\end{array}$ & 0.946 & 0.946 & 0.946 & 0.946 & 0.946 & 0.946 \\
\hline $\begin{array}{c}\text { Revenue growth, } \\
\text { thousand rubles } \\
\text { Additional }\end{array}$ & 2,772 & 3,184 & 3,740 & 5,754 & 7,864 & 12,470 \\
$\begin{array}{c}\text { investments in } \\
\text { assets, thousand } \\
\text { rubles }\end{array}$ & 1,054 & 1,211 & 1,423 & 2,192 & 2,997 & 4,756 \\
\hline $\begin{array}{c}\text { including } \\
\text { additional loan }\end{array}$ & 781 & 938 & 1,150 & 1,919 & 2,724 & 4,483 \\
\hline
\end{tabular}

The calculation of these indicators in the example is made on the basis of planned increase in net profit, the set rate of return on equity (ROE) equal to 12 percent and the constant turnover of assets.

The basis of calculations is balancing of planned income and operational and financial risks. The main factor is the operational risk taken into account through the share of variable (fixed) costs in the cost of products. The higher the share of variable costs (the less the share of fixed costs) in the cost of products, the lower the level of operational risk is, and, therefore more revenue and investment in assets are required having one and the same plan for net profit and return on equity. At the same time, the main indicators of the company's financial risk like debt ratios $(0.56-0.77)$ and financial independence $(0.57-$ 0.45 ) vary within the limits of the standards for financially stable enterprises.

The following ratios are used in the calculations:

- Asset turnover (turnover per year) = Annual sales / Average annual value of assets

$$
\mathrm{AT}=\mathrm{AS} / \mathrm{Vaa}
$$

- Return on sales $=$ Profit on sales $/$ Annual sales

$$
\text { ROS }=\text { Ps/AS }
$$

- Return on assets $=$ Net profit + Interest paid on loan / Average annual value of assets

$$
\mathrm{ROA}=(\mathrm{Np}+\mathrm{LPI}) / \mathrm{Vaa}
$$


- Return on equity $=$ Net profit / Average annual equity value of the company

$$
\mathrm{ROE}=\mathrm{Np} / \mathrm{CVaa}
$$

- Debt ratio $=$ Short-term bank credit (loan) / Volume of sale for the quarter;

$$
\mathrm{Dr}=\mathrm{ShBK} / \mathrm{SVq}
$$

- Financial independence ratio $=$ Average annual cost of equity of the company / Average annual value of assets

$$
\mathrm{FIr}=\mathrm{CV} / \mathrm{Vaa}
$$

- Operating leverage $=$ Marginal profit $/$ Profit from sales;

$$
\mathrm{OL}=\mathrm{Pm} / \mathrm{Ps}
$$

- Revenue growth rate $=$ Rate of profit growth from sales / Operating leverage;

$$
\operatorname{Rrg}=\operatorname{Rspg} / \mathrm{OL}
$$

\section{Conclusion}

The following conclusions were made based on the study of the changes in operational risks at enterprises as a result of budgeted sales increase or decrease.

At the stages of development and sales growth the percentage of fixed costs at enterprises decreases and, therefore, the level of risks, determined by such indicators as operating leverage and a break-even point, also decreases. Lower operational risks mean slower operating income growth as compared to sales growth. Risk retention is required to maintain the rate of operating income growth in such a situation. It can be achieved by increasing the percentage of fixed costs in the cost of production. At the stages of production growth it is thus cost-efficient to hire employees with fixed salaries and increase investments in environmental activities, which leads to an increase in the percentage of fixed costs in the cost of production.

The situation is exactly the opposite at the stages of recession and sales slowdown. In this case the percentage of fixed costs in the cost of production increases and the level of operational risks rises drastically. To retain the planned level of risk it is necessary to implement personnel management projects aimed at employing less people with fixed salaries and reducing fixed costs associated with environmental activities. In such a situation it becomes cost-efficient to cut fixed costs.

The results of the study provide the opportunity to manage the operational risks of the company at the stage of planning and financing of environmental measures by modeling processes and monitoring various development situations

\section{References}

1. E.M. Sergeev, Urban Environment: Rational Use and Protection (Aspect Press, Moscow, 2006)

2. O.N. Yanitsky, Ecological Economics (Piter, St. Petersburg, 2007)

3. K. Skene, A. Murray, Sustainable Economics: Context, Challenges and Opportunities for the 21st-Century Practitioner (Taylor and Francis Inc., Oxford, 2017)

4. K. John, A.K. Makhija, S.P. Ferris. Global Corporate Governance. (Emerald Group Publishing LTD, London, 2017) 
5. N. Silver, Finance, society and sustainability: How to make the financial system work for the economy, people and planet. (Palgrave Macmillan, London, 2017)

6. A.Ya. Kibanov, Human Resource Management of Organization: Theory and Practice. Evaluation of the Economic and Social Effectiveness of Human Resource Management of Organization. (Prospekt, Moscow, 2015)

7. E.A. Mitrofanova, L.V. Ivanovskaya, Human Resource Management of Organization: Theory and Practice. Employee Performance Evaluation and Evaluation of Human Resource Management. (Prospekt, Moscow 2013)

8. I.V. Ilin, O.V. Rostova, Investment Management. (Publishing house of Polytechnic, St. Petersburg, 2017)

9. O.A. Ahalaya, O.V. Kalinina. Innovation Human Resource Management of Organization: Change Management (Publishing house of Polytechnic, St. Petersburg, 2017)

10. S. Nie, Y.P. Li, J. Liu, C.Z. Huang, Energy Econ. 61, 313 (2017)

11. P. Boateng, Z. Chen, S.O. Ogunlana, IJPM 33 (8), 1795 (2015)

12. B.A. Nicholds, J.P.T. Mo, JMTM 29(6), 1003 (2018)

13. N. Stojcic, I.Hashi, E. Orlic, EJIM 21, 564 (2018)

14. R.A. Baron, J. Tang, JBV 26 (1), 49 (2011)

15. A. Kianto, J. Sáenz, N. Aramburu, JBR 81, 11 (2017) 